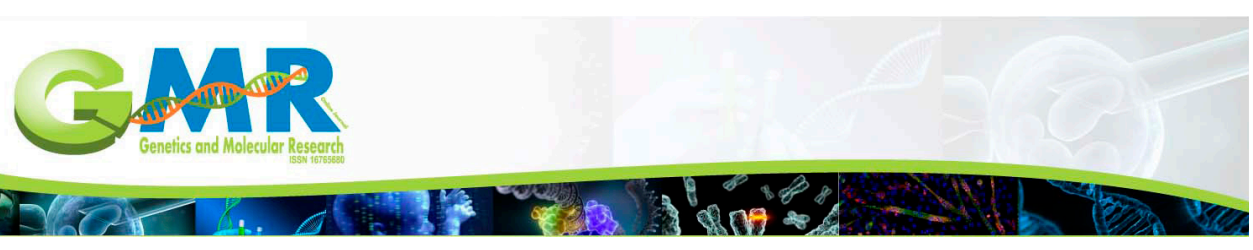

\title{
Crossability of Arachis valida and B genome Arachis species
}

\author{
D.C. Wondracek-Lüdke ${ }^{1,2}$, A.R. Custodio ${ }^{2}$, C.E. Simpson ${ }^{3}$ and J.F.M. Valls ${ }^{4}$ \\ 1Programa de Pós-Graduação em Botânica, Universidade de Brasília, Brasília, \\ DF, Brasil \\ ${ }^{2} \mathrm{CNPq} /$ Embrapa Recursos Genéticos e Biotecnologia, Brasília, DF, Brasil \\ ${ }^{3}$ Texas A\&M AgriLife Research, Stephenville, TX, USA \\ ${ }^{4}$ Embrapa Recursos Genéticos e Biotecnologia, Brasília, DF, Brasil \\ Corresponding author: D.C.Wondracek-Lüdke \\ E-mail: daniele.wondracek@gmail.com
}

Genet. Mol. Res. 14 (4): 17574-17586 (2015)

Received May 6, 2015

Accepted September 11, 2015

Published December 21, 2015

DOI http://dx.doi.org/10.4238/2015.December.21.30

ABSTRACT. The peanut (Arachis hypogaea) is an important food crop in much of the tropical and semi-tropical parts of the world. The peanut is an allotetraploid with an $A A B B$ genome formula derived from diploids A. duranensis (A genome) and A. ipaënsis (B genome). The success of an introgression program that aims to improve cultivated varieties of the peanut depends on whether the chosen $B$ genome species is homologous with the $B$ genome of the peanut. While not directly involved in the origin of the peanut to the best of our knowledge, Arachis valida is a B genome species that could potentially be a bridge species or a source of new and different alleles, because of its resistance to diseases and pests. In this study, we investigated the crossability of $A$. valida with five other $B$ genome species of section Arachis. Eight cross-combinations were made with $A$. valida and A. gregoryi, A. ipaënsis, A. magna, A. valida, and $A$. williamsii. Two hundred and forty pollinations were made yielding 61 fruit segments, 61 seeds, one abortion, and 24 hybrid plants. An analysis of the morphological characteristics and pollen viability confirmed that the plants 
were hybrids. Our results indicated that higher pollen viability of hybrid plants corresponded with higher affinity between parent plants used in crossings. This conclusion corroborates much of previous research carried out by many other authors in the past.

Key words: Peanut; Groundnut; Wild species; Pre-breeding; Pollen; Artificial hybridization

\section{INTRODUCTION}

Arachis L. is a South American genus of 81 species that thrives in Brazil, Bolivia, Paraguay, Argentina, and Uruguay, ranging from north-northeastern Brazil, just south of the equator, to the northern bank of the Rio de la Plata in Uruguay and from the Atlantic coast to the eastern foothills of the Andes (Krapovickas and Gregory, 1994; Valls and Simpson, 2005; Valls et al., 2013). Brazil has the largest number of species including 47 endemic species and 17 native species shared (Krapovickas and Gregory, 1994; Valls and Simpson, 2005; Valls et al., 2013). The peanut ( $A$. hypogaea L.), also known as the groundnut, is cultivated in over 100 countries, and China, India, Nigeria and United States of America were the top producers in 2013 (FAOSTAT, 2015). The peanut is one of the most important sources of protein in the world and peanut oil is the most important peanut derived product (Burow et al., 2009). In 2012, over five million tons of peanut oil were produced (FAOSTAT, 2015). Peanuts are consumed raw, roasted, as peanut butter, in confectionary candies and as oil for cooking and food preparation.

The genus is classified into nine taxonomic sections and the cultivated peanut belongs to section Arachis (Krapovickas and Gregory, 1994). Within the section Arachis, the genomes A, B, D, F, G, K, and AB can be found based on observations of karyotype structures (Stalker, 1991; Krapovickas and Gregory, 1994; Peñaloza and Valls, 2005; Robledo et al., 2009; Robledo and Seijo, 2010; Silvestri et al., 2015). One species, that crosses with many species of section Arachis, A. vallsii Krapov. \& W.C. Greg., still has an unknown genome. The diploid species characterized by the presence of one small pair of chromosomes, or "A chromosomes", are known as the A genome species. These chromosomes have differential staining from the centromere, slight staining in the prometaphase, and one heterochromatic band at the centromeric region (Husted, 1933, 1936; Seijo et al., 2004). The A genome species can be divided into three subtypes based on the variability observed during molecular analysis, in fluorescence in situ hybridization (FISH) mapping, and heterochromatin detection, and over their geographic distribution: the La Plata River Basin Group, the Chiquitano Group, and the Pantanal Group (Robledo et al., 2009). The annual diploid species of section Arachis with a chromosome number of $2 n=2 x=20$, lacking pair $A$, was formally known as the non-A genome, or B genome species (Peñaloza and Valls, 2005; Valls and Simpson, 2005; Robledo and Seijo, 2010). Two of these species, A. benensis Krapov., W.C. Greg. \& C.E. Simpson and $A$. trinitensis Krapov. \& W.C. Greg., were re-evaluated and classified as F genome species (Robledo and Seijo, 2010), while the other three species, A. batizocoi Krapov. \& W.C. Greg., A. cruziana Krapov., W.C. Greg. \& C.E. Simpson, and A. krapovickasii C.E. Simpson, D.E. Williams, Valls \& I.G. Vargas were classified as K genome species, based on molecular studies and by FISH mapping (Robledo and Seijo, 2010). Quite recently, three additional annual species of the section Arachis with a chromosome number of $2 n=2 x=18$, lacking pair $A$, were reclassified as $G$ genome species (Silvestri et al., 2015). Non-A genome species have not been studied thoroughly, and their relationships among these taxa are unclear (Robledo and Seijo, 2010). 
Modern peanut-breeding programs seek introgression of desirable agronomic traits, such as increased productivity and quality, resistance and/or tolerance to diseases and pests and tolerance to drought and flooding. These aforementioned agronomic traits of wild species can be transferred to peanut by crosses. Several peanut cultivars were developed in this way, such as COAN, NemaTAM, and Tifguard (Simpson and Starr, 2001; Simpson et al., 2003; Church et al., 2005; Holbrook et al., 2008).

Peanut is an allotetraploid with a chromosome number of $2 n=4 x=40$ and an $A B$ genome (Kochert et al., 1996). Through cytogenetic and molecular analyses, the two wild diploid species A. duranensis Krapov. \& W.C. Greg. (provider of the A genome) and A. ipaënsis Krapov. \& W.C. Greg. (provider of the B genome) were found to be the parents of $A$. hypogaea (Fávero et al., 2006; Seijo et al., 2004, 2007; Grabiele et al., 2012). Identifying a species with high homology to the B genome of $A$. hypogaea is important because the success of introgression breeding programs greatly depends on the choice of a species with $B$ genome compatibility with that of the peanut (Cunha et al., 2008). Thus, understanding the relationship between various B genome species is important and justifies further intensive study. There are more than 50 available $A$. duranensis accessions (A genome). However, only one germplasm accession is available for $A$. ipaënsis (B genome), an endemic species to Bolivia. There are four other $B$ genome species. One is an endemic species to Bolivia: A. williamsii Krapov. \& W.C. Greg. Another is endemic to Bolivia and Brazil: A. magna Krapov., W.C. Greg. \& C.E. Simpson. The final two are endemic only to Brazil: $A$. gregoryi C.E. Simpson, Krapov. \& Valls (Valls and Simpson, 2005) and A. valida Krapov. \& W.C. Greg. (Krapovickas and Gregory, 1994; Valls and Simpson, 2005). These species are cytologically similar to $A$. ipaënsis because their chromosomes do not have heterochromatic bands (Robledo and Seijo, 2010). By cytogenetic and molecular analyses and crosses, $A$. valida has been found to be close to A. ipaënsis (Custodio, 2009; Custodio et al., 2013; Moretzsohn et al., 2013). A. valida has a higher number of accessions compared to the only one available accession of $A$. ipaënsis, needed to expand the genetic basis for the $\mathrm{B}$ genome in peanut-breeding programs. Another species is $A$. magna, which has higher intra-population heterogeneity, indicating that this species could comprise more than one taxon (Custodio et al., 2013). A. valida is possibly tolerant to flooding and may have disease resistance associated with excessive moisture because it grows in sites flooded during the wet season south of Mato Grosso do Sul in the Pantanal (Krapovickas and Gregory, 1994). Some accessions have resistance to early leaf spot (Cercospora arachidicola Hori), late leaf spot (Cercosporidium personatum (Berk \& Curt.) Deighton), rust (Puccinia arachidis Speg.), and corn caterpillar infestations (Spodoptera frugiperda Smith) (Pande and Rao, 2001; Ramos, 2007; Fávero et al., 2009). A. valida is not directly involved in the origin of peanut, but it is valuable to have information about its crossability with other species, because it could potentially be used in peanut-breeding programs as a bridge species or as a source of new and different alleles. The objective of this study was to characterize the taxonomic relationships among $A$. valida and other B genome species of section Arachis through crosses between species.

\section{MATERIAL AND METHODS}

\section{Date and location of experiments}

The experiments were carried out between September 2011 and March 2013 at Embrapa Genetic Resources and Biotechnology (Embrapa Cenargen), in the Federal District of Brasília, Brazil, $15^{\circ} 43^{\prime} 51.63^{\prime \prime S}, 47^{\circ} 54^{\prime} 05.17^{\prime \prime} \mathrm{W}, 1020 \mathrm{~m}$. 


\section{Plant material source}

The seeds for the accessions were obtained from the Active Germplasm Bank of Wild Species of Arachis at Embrapa Genetic Resources and Biotechnology (BAG Arachis - Cenargen) (Table 1).

Table 1. Materials of Arachis species of section Arachis, abbreviations, and collector numbers; Brazilian accession code (BRA); municipality; state and country of origin; geographic coordinates: latitude (Lat) and longitude (Long) in degrees $\left({ }^{\circ}\right)$ and minutes $(')$, and altitude (Alt) in meters; genome; and ploidy level (2n).

\begin{tabular}{|c|c|c|c|c|c|c|c|c|c|}
\hline Species & Collector ${ }^{*} \mathrm{~N}^{\circ}$ & BRA & Municipality - State & Country & Lat. (S) & Long. (W) & Alt. $(\mathrm{m})$ & Genome & $2 n$ \\
\hline $\begin{array}{l}\text { Arachis gregoryi C.E. Simpson, } \\
\text { Krapov. \& Valls }\end{array}$ & VS 14957 & 040002 & Vila Bela S. Trindade - MT & Brazil & $15^{\circ} 22^{\prime}$ & $60^{\circ} 14^{\prime}$ & - & B & 20 \\
\hline A. ipaënsis Krapov. \& W.C. Gregory & KGBPScS 30076 & 036234 & Ipa & Bolivia & $21^{\circ} 00^{\prime}$ & $63^{\circ} 25^{\prime}$ & 650 & B & 20 \\
\hline $\begin{array}{l}\text { A. magna Krapov., W.C. Gregory } \\
\text { \& C.E. Simpson }\end{array}$ & KGScS 30097-of & 036871 & San Ignacio de Velasco & Bolivia & $16^{\circ} 22^{\prime}$ & $60^{\circ} 58^{\prime}$ & 370 & B & 20 \\
\hline A. magna & VOfSv 14707 & 034011 & Cáceres - MT & Brazil & $15^{\circ} 48^{\prime}$ & $58^{\circ} 23^{\prime}$ & 150 & B & 20 \\
\hline A. magna & VOfSv 14724 & 033839 & Vila Bela S. Trindade - MT & Brazil & $15^{\circ} 19^{\prime}$ & $60^{\circ} 03^{\prime}$ & 390 & B & 20 \\
\hline A. magna & VOfSv 14727 & 033847 & Vila Bela S. Trindade - MT & Brazil & $15^{\circ} 21^{\prime}$ & $60^{\circ} 04^{\prime}$ & 380 & B & 20 \\
\hline A. valida Krapov. \& W.C. Gregory & VPzRcSgSv 13514 & 032620 & Corumbá - MS & Brazil & $19^{\circ} 07^{\prime}$ & $57^{\circ} 32^{\prime}$ & 70 & B & 20 \\
\hline A. valida & VS 15096 & 040410 & Corumbá - MS & Brazil & $19^{\circ} 18^{\prime}$ & $57^{\circ} 36^{\prime}$ & - & B & 20 \\
\hline A. williamsii Krapov. \& W.C. Gregory & WiDc 1118 & 036897 & Trinidad & Bolivia & $14^{\circ} 48^{\prime}$ & $64^{\circ} 52^{\prime}$ & - & B & 20 \\
\hline
\end{tabular}

${ }^{*}$ Collector: Dc = D. Claure, K = A. Krapovickas, Of = F.O. Freitas, P = J. Pietrarelli, Pz = E.A. Pizarro, Rc = R.C. Oliveira, S = C.E. Simpson, Sc = A. Schinini, Sg = A.K. Singh, Sv = G.P. Silva, V = J.F.M. Valls, Wi = D.E. Williams. of: orange flower. S. Trindade: Santíssima Trindade. MS: Mato Grosso do Sul. MT: Mato Grosso.

\section{Seed germination}

The seed germination was carried out at the Laboratory of Cytogenetics at Embrapa Genetic Resources and Biotechnology, in a TE - 40 I Tecnal germination chamber at $25^{\circ} \mathrm{C}$ with a 12-h light and 12-h dark photoperiod. Seeds were rolled in germitest paper moistened with distilled water. Some seeds developed a fungus and were treated with 1:5 (v/v) tetramethylthiuram disulfide (Thiram). The dormant seeds were treated with $1 \%$ Ethrel solution (2-chloroethylphosphonic acid - Etefom). After the emergence of primary roots and growth of secondary roots, seedlings were transplanted into plastic cups of soil with a 1:1 ratio red soil to sand, or a super-thin grade of expanded vermiculite. Later, seedlings were transplanted in pots with a soil mixture of $1 \mathrm{~kg}$ ammonium sulfate, $2 \mathrm{~kg}$ lime, $4 \mathrm{~kg}$ simple superphosphate, $700 \mathrm{~kg}$ red soil, and $700 \mathrm{~kg}$ sand.

\section{Hybridization technique}

The crosses were performed between January 2012 and April 2012 in a screenhouse at Embrapa Genetic Resources and Biotechnology. The conventional hybridization technique was used with some adaptations described below. One male parent flower was used to pollinate one female parent flower (Nigam et al., 1990). One day before anthesis of the flower buds on the female parents, emasculation was performed by removing the anthers between 16:00 and 19:00. Pollination was performed between 7:00 and 10:00 the next day. Before pollination, water was sprayed on the emasculated flower stigmas to aid in the fixation of pollen grains. The keel and the anthers of male parents were cut and placed on the stigmas of the emasculated flowers covering it and part of the style. One to three male parent plants were used to pollinate each crosscombination. The crosses were performed as many times as needed to obtain at least three pegs for each combination. The harvest was conducted at the end of the life cycle of $A$. valida. The seeds 
were germinated for analysis of successful crosses. Germination of seeds and crosses for the next generation followed the same procedures as for germination of seeds for the parents. The seeds that germinated in pots of female plants were transplanted to pots having the same soil mixture used for the pots of the parents. The success rate of crosses was calculated using the following equation:

$$
\% \mathrm{SC}=(\mathrm{NH} / \mathrm{NPO}) \times 100
$$

where percentage SC is the success rate of the crossing, NH is the number of hybrids, and NPO is the number of pollinations (Fávero, 2004).

\section{Pollen viability analysis}

A pollen viability analysis was performed by visually counting the stained pollen grains of the parent and hybrid flowers. The analysis was made by a random collection of ten flowers from each parent and a variable number from the hybrids. The flowers were collected between 7:00 and 10:00. The analysis was performed at the Laboratory of Cytogenetics at Embrapa Genetic Resources and Biotechnology. A maceration of the anthers was made with aceto-carmine:glycerine $2 \%$. At least 500 -pollen grains per sample were made by counting the number of grains present per sample at random (Guerra and Souza, 2002). The pollen grains that were well-formed and well-stained were considered viable. The average number of viable-stained pollen grains found per flower was calculated. The results are reported as a percentage of estimated viability.

\section{Morphological characterization}

We confirmed hybridizations and conducted morphological characterizations by using the germination descriptors of each Arachis species, including epicotyl length, epicotyl hairiness, presence/absence of anthocyanin in the epicotyl; hypocotyl length, hypocotyl hairiness, presence/ absence of anthocyanin in the hypocotyls; cotyledon and petiole lengths; and presence/absence of anthocyanin in the petioles and cotyledons (Carpes, 2010). Morphological descriptors for wild Arachis species were also used including the presence or absence of small, scattered, adpressed hairs on the lower surface of small leaflets; the presence, or absence of long, dense, wavy hairs on the lower surface of long leaflets; and the presence or absence of bristles on the stipules (IBPGR/ ICRISAT, 1992).

\section{RESULTS AND DISCUSSION}

\section{Crosses}

Arachis valida formed hybrids with all five B genome species: A. gregoryi, A. ipaënsis, $A$. magna, $A$. valida, and $A$. williamsii. Two hundred and forty-five pollinations were performed. The number of pollinations was different among cross-combinations due to the difference of available number of male and female parent flowers. Sixty-one fruit segments and 61 seeds were harvested. Only one aborted seed was found in an A. valida V 13514 x A. magna V 14724 cross-combination. Twentyfive hybrid plants were confirmed. The hybrid plants were obtained by spontaneous germination of seedlings in pots containing female parent or by seed germination in a germination chamber (Table 2). 
Table 2. Crossability data between Arachis valida and B genome Arachis species.

\begin{tabular}{|c|c|c|c|c|c|c|c|c|c|c|c|c|c|}
\hline $\begin{array}{l}\text { Cross combination } \\
\text { A. valida } \mathrm{V} 13514 \mathrm{x}\end{array}$ & NPO & NFS & NS & NAB & $\mathrm{NH}$ & SC\% & PVP\% & $\mathrm{PVH} \%$ & $\mathrm{NSH}$ & $\mathrm{NABH}$ & $\begin{array}{l}\text { Small } \\
\delta / \% / \mathrm{H}\end{array}$ & $\begin{array}{l}\text { Long } \\
\delta / 9 / \mathrm{H}\end{array}$ & $\begin{array}{c}\mathrm{BS} \\
\delta / 9 / \mathrm{H}\end{array}$ \\
\hline A. valida $\vee 15096$ & 34 & 8 & 8 & 0 & 5 & 14.7 & $99.3 \pm 0.4$ & $98.4 \pm 1.8$ & 59 & 12 & $-/-/-$ & $-/-/-$ & $-/-/-$ \\
\hline A. magna $\vee 14707$ & 5 & 1 & 1 & 0 & 1 & 2.0 & $99.4 \pm 0.3$ & $39.4 \pm 0.0$ & 10 & 3 & $+/-/+$ & $-/-/-$ & $+/-1-$ \\
\hline A. magna $\mathrm{V} 14727$ & 40 & 14 & 14 & 0 & 5 & 12.5 & $99.4 \pm 0.8$ & $29.6 \pm 5.4$ & 3 & 2 & $+/-/+$ & $-/-/-$ & $+/-/+$ \\
\hline A. magna $\vee 14724$ & 86 & 16 & 16 & 1 & 5 & 5.8 & $99.2 \pm 0.7$ & $27.5 \pm 3.6$ & 7 & 1 & $+/-/+$ & $-1-/$ & $+/-1+$ \\
\hline A. ipaënsis K 30076 & 12 & 2 & 2 & 0 & 1 & 8.3 & $99.1 \pm 0.6$ & $25.3 \pm 3.6$ & 1 & 0 & $+/-/+$ & $-/-/-$ & $-/-/-$ \\
\hline A. magna $\mathrm{K}$ 30097-of & 30 & 7 & 7 & 0 & 4 & 13.3 & $99.5 \pm 0.7$ & $25.3 \pm 6.1$ & 20 & 3 & $+/-1+$ & $-/-/-$ & $-/-/-$ \\
\hline A. williamsii Wi 1118 & 16 & 5 & 5 & 0 & 2 & 12.5 & $99.3 \pm 0.7$ & $18.6 \pm 2.5$ & 0 & 0 & $-1-/+$ & $-1-1-$ & $-1-/-$ \\
\hline A. gregoryi $\vee 14957$ & 22 & 4 & 4 & 0 & 2 & 9.1 & $98.0 \pm 0.9$ & $10.5 \pm 2.1$ & 0 & 0 & $-/-/$ & $+/-/+$ & $+/-1+$ \\
\hline Total & 245 & 61 & 61 & 1 & 25 & & & & 100 & 21 & & & \\
\hline
\end{tabular}

Collector: $\mathrm{K}=\mathrm{A}$. Krapovickas, $\mathrm{V}=$ J.F.M. Valls, $\mathrm{Wi}=\mathrm{D}$.E. Williams. $\mathrm{H}$ : hybrid, of: orange flower, $\delta^{\lambda}$ : male,, : female. Cross combination, number of pollinations (NPO), number of fruit segments (NFS), number of seeds (NS), number of aborted seeds $(N A B)$, number of confirmed hybrids $(N H)$, success rate of the cross $(S C \%=(N H / N P O) \times 100)$, pollen viability of male parents (PVP\%), pollen viability of hybrids ( $\mathrm{PVH} \%$ ), number of seeds of hybrids (NSH), number of aborted seeds of hybrids (NABH), presence or absence of small, scattered, adpressed hairs on lower surface of leaflets (Small), presence $(+)$ or absence $(-)$ of long, dense, wavy hairs on lower surface of leaflets (Long) and presence $(+)$ or absence $(-)$ of bristles on stipules (BS) in parents and hybrids.

The ease of obtaining the peg did not guarantee the obtaining of a hybrid. The success rate of the crosses made was not related to the greatest number of successful pollinations. The success rate of the crossings varied even among cross-combinations made of the same species. The success rate varied between crosses of $A$. valida and four $A$. magna accessions. The rate of success calculated for $A$. valida $\times A$. magna ranged from $2.0 \%$ in $A$. valida $\vee 13514 \times A$. magna $\vee 14707$ up to $13.3 \%$ in $A$. valida $V 13514 \times$ A. magna $\mathrm{K} 30097$-of. Over all, the highest rate of success for a crosscombination was $14.7 \%$ of $A$. valida $\vee 13514 \times A$. valida $\vee 15096$, and the lowest rate of success for a cross-combination was $2.0 \%$ of $A$. valida $\vee 13514$ x A. magna $\vee 14707$ (Table 2).

\section{Pollen viability}

The fertility of the hybrids is one of the tools used to determine the degree of genetic isolation (Krapovickas and Gregory, 1994). In general, organisms that are closely related are more likely to be interfertile (Anderson, 1949).

Variations in pollen viability were observed in previous studies of Arachis. The pollen viability of 100 parents of Arachis species has been used in intrasectional and intersectional cross experiments and varied between 55.6 and $99.6 \%$ (Gregory and Gregory, 1979). The pollen viability of the male parents of the $\mathrm{B}$ genome species used in crosses with $A$. gregoryi varied between $71.9 \%$ in A. valida V 13514 , all the way up to $99.2 \%$ in A. magna K 30097-of (Custodio, 2009). The range of variation was wider than in our present study because of the use of different accessions; however, the species used were the same.

The pollen viability of the parents for the present study was over $97 \%$ (Table 2), which is considered a satisfactory value, and along a success rate of over $30 \%$ for cross-combinations (Einhardt et al., 2006). Most of the pollen grains of the parents were well-formed in structure and were well-stained (Figure 1A). The pollen viability of the male parent varied between $98.0 \pm 0.9 \%$ for $A$. gregoryi $\bigvee 14957$ and $99.5 \pm 0.7 \%$ in A. magna K 30097 -of (Table 2). The pollen viability of the female parent of $A$. valida $\vee 13514$ was $98.1 \pm 1.6 \%$. The pollen viability of the male parent of A. valida $V 15096$ was $99.3 \pm 0.4 \%$ (Table 2 ). In this study, the highest pollen viability shown for the hybrids was $98.4 \%$ in the intraspecific cross of $A$. valida $\vee 13514 \times$ A. valida $\vee 15096$ (Table 
2), whereas Custodio (2009) reported the highest pollen viability from the intraspecific cross of $A$. gregoryi $\vee 14957 \times A$. gregoryi $\vee 14753$ as $43.6 \%$. The lowest pollen viability of the present study was $10.5 \%$ for $A$. valida $\vee 13514 \times$ A. gregoryi $\vee 14957$ (Table 2), and Custodio (2009) reported the reciprocal cross of $A$. gregoryi $\vee 14957 \times A$. valida $\vee 13514$ to have a pollen viability of $5.5 \%$.

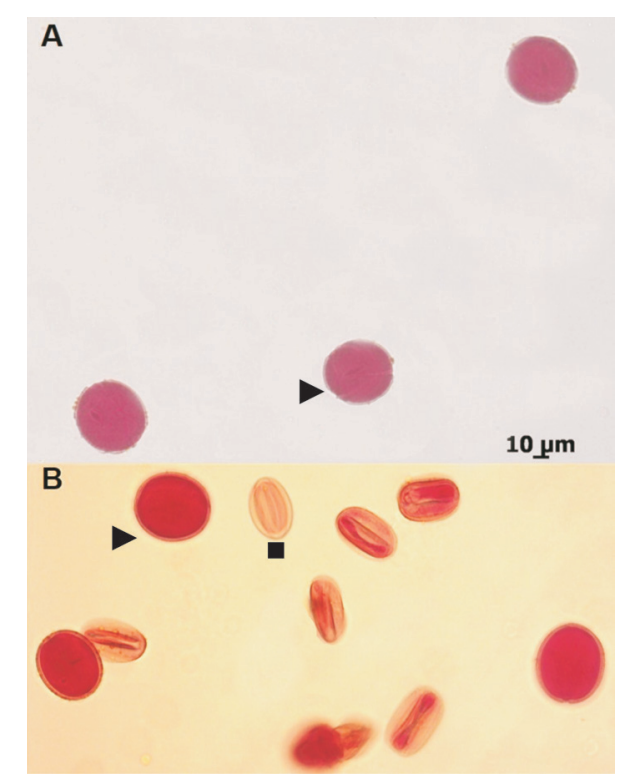

Figure 1. A. Pollen of female parent Arachis valida V 13514. B. Pollen of Arachis valida $V 13514 \times$ Arachis magna V 14707 hybrid. Arrowheads $=$ well-formed in structure and well-stained pollen grains. Square $=$ malformed and unstained pollen grains. Scale bar $=10 \mu \mathrm{m}$.

The low pollen viability of the hybrids $A$. valida $\vee 13514 \times A$. gregoryi $\vee 14957, A$. valida $\vee 13514$ x A. ipaënsis K 30076, A. valida V 13514 x A. magna K 30097-of, A. valida V 13514 x A. magna $\vee 14707$, A. valida $\vee 13514 \times A$. magna $\vee 14724$, A. valida $\vee 13514 \times A$. magna $\vee 14727$, and $A$. valida $\vee 13514 \times A$. williamsii Wi 1118 (Table 2) indicates hybrid sterility, which is a postzygotic mechanism involved in the attempted formation of hybrids (Stebbins, 1958).

Anther dehiscence is related to the pollen viability. In wild Arachis species, anther dehiscence is normal when pollen viability is above $50 \%$. Anthers open with difficulty when the pollen viability is below $50 \%$. The anthers are indehiscent when pollen viability is around $25 \%$; however, pollen can still be captured by bees. Anthers must be dissected to extract pollen when viability is below $15 \%$. When viability is below $10 \%$, it is questionable whether pollen grains, when stained, can still function during pollination (Krapovickas and Gregory, 1994). As the pollen viability of the intraspecific hybrid $A$. valida $\vee 13514 \times$ A. valida $\vee 15096$ and the hybrid $A$. valida $\vee 13514$ $x A$. magna $\vee 14727$ was higher than $50 \%$ (Table 2), the anther dehiscence of the flowers of these hybrids was normal. The hybrids $A$. valida $\vee 13514$ x A. magna K 30097-of, $A$. valida $\vee 13514 \times A$. magna $\vee 14707$, A. valida $\vee 13514 \times$ A. magna $\vee 14724$ and $A$. valida $\vee 13514 \times A$. magna $\vee 14727$ had pollen viability between 25.0 and $40.0 \%$ (Table 2). The anthers of flowers of these hybrids opened with difficulty and released pollen only when handled. As the pollen viability of the hybrids A. valida $\vee 13514 \times$ A. williamsii Wi 1118 and $A$. valida $\vee 13514 \times$ A. gregoryi $\vee 14957$ was below $20 \%$ (Table 2) the anthers of these hybrids were indehiscent. 
In the pollen viability analysis of hybrids many malformed and unstained pollen grains were observed (Figure 1B). The occurrence of malformed pollen grains of these hybrids could be due to irregularities in the disjunction, e.g., the separation of chromosomes as shown in trisomy and some hybrids, the variable tendency to form quadrivalents, exchange of non-target homologous chromosomes and chromosome rearrangements (Poole, 1932).

\section{Hybrid seed production}

All hybrids produced orange flowers and pegs. However, in the hybrid crosses, $A$. valida $\mathrm{V} 13514 \times$ A. gregoryi $\mathrm{V} 14957$ and $A$. valida $\mathrm{V} 13514 \times$ A. williamsii Wi 1118, there was no production of fruit segments or seeds. From the other hybrids, one hundred seeds were obtained. It is likely that in 21 (Table 2), an abortion of the embryo occurred. Empty fruit segments, fruit segments with small and malformed seeds or blackened seed remnants were observed. Tallury et al. (2005) also found fruit segments with aborted seeds in crosses between A. duranensis with $A$. benensis, $A$. cruziana, A. palustris, and A. praecox. In the same study, in crosses between $A$. batizocoi with $A$. benensis, $A$. palustris and $A$. praecox, fruit segments with aborted embryos were recovered. Abortion of an embryo is a post-zygotic mechanism that may be caused by disharmony between genotype hybrid zygote and endosperm or maternal tissue (Stebbins 1958); this may have occurred in the A. valida hybrids of this study. All Arachis species produce pods below ground, which makes it difficult to do reproductive monitoring in interspecific crosses where the embryo often is aborted. Although pegs may appear to be healthy for several weeks after fertilization, embryos of many interspecific crosses exhibit slow growth during this period, leading to an abortion at a later stage (Tallury et al., 1995). Several processes can lead to failure to produce peanut hybrids: lack of fertilization, delayed fertilization, inability of the proembryo to resume growth after penetration of the peg into the ground, and slow growth of the proembryo. The lack of fertilization is a pre-zygotic mechanism. Late fertilization, proembryo inability to resume growth after the peg penetrates the soil, and the slow growth of the proembryo are post-zygotic mechanisms (Tallury et al., 1995).

\section{Morphological characterization of adult plants}

Leaflets of the adult hybrid plants on the main stem had the same or similar shape as the female parent, A. valida (Figure 2A). However, in the lateral branches, the leaflets had the same or apparently similar shape as the leaflets of the male parents (Figure 2B, C, D). Other characteristics inherited from the parents were the presence or absence of hairs and bristles.

The presence or absence of small, scattered, adpressed hairs on the lower surface of leaflets was observed in parents and hybrids (Figure 2E, F). The male parent accessions of $A$. magna K 30097-of, V 14707, V 14724, V 14727, and A. ipaënsis K 30076 have small, scattered, adpressed hairs on the lower surface of leaflets, and as a result of crosses performed with these parents, the hybrids have these hairs as well. The female parent $A$. valida $\mathrm{V} 13514$ and the male parent $A$. williamsii Wi 1118 do not have small, scattered, adpressed hairs on the lower surface of leaflets, but the hybrid $A$. valida V 13514 x A. williamsii Wi 1118 does have hairs (Table 2).

The presence or absence of long, dense, wavy hairs on the lower surface of leaflets was also observed in parents and hybrids. Only the male parent $A$. gregoryi $\vee 14957$ and the hybrid $A$. valida $\vee 13514$ x A. gregoryi $\vee 14957$ had long, dense, wavy hairs on the lower surface of leaflets (Table 2 and Figure $3 A, B$ ). 


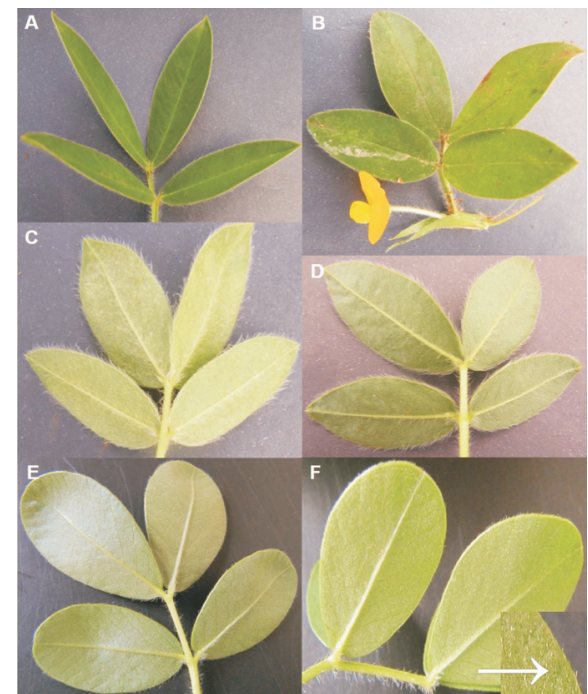

Figure 2. A. Leaf from main stem of female parent Arachis valida $V 13514$. B. Leaf from lateral branch of male parent Arachis valida $\vee$ 15096. C. Leaf from lateral branch of male parent Arachis gregoryi $\vee$ 14957. D. Leaf from lateral branch of Arachis valida V 13514 x Arachis gregoryi V 14957 hybrid. E. Glabrous lower surface of leaf of seedling of female parent Arachis valida V 13514. F. Adpressed hairs on lower surface of leaf from seedling of Arachis valida $\mathrm{V}$ 13514 x Arachis magna $\vee 14727$ hybrid (arrow).

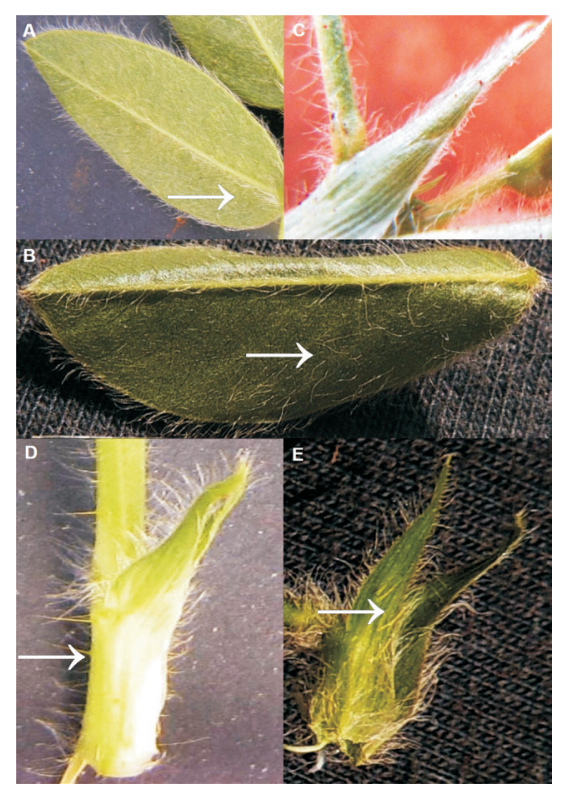

Figure 3. A. Villous lower surface (arrow) of leaflet from lateral branch of male parent Arachis gregoryi $\vee$ 14957. B. Villous lower surface (arrow) of leaflet from lateral branch of Arachis valida $\vee 13514$ x Arachis gregoryi $\vee 14957$ hybrid. C. Stipule without bristles on leaf from lateral branch of female parent Arachis valida V 13514. D. Stipule with bristles (arrow) on leaf from lateral branch of male parent Arachis gregoryi V 14957. E. Stipule with bristles (arrow) on leaf from lateral branch of Arachis valida V 13514 x Arachis gregoryi V 14957 hybrid. 
The presence or absence of bristles on the stipules was another characteristic observed in parents and hybrids (Table 2 and Figure 3C, D, E). The hybrids that had male parents with bristles on stipules showed the same characteristic (Figure 3D, E). The male parents, A. magna $\mathrm{V} 14724$, $\mathrm{V} 14727$, A. gregoryi $\mathrm{V} 14957$, and their hybrids had bristles on their stipules. The exception was A. valida $\mathrm{V} 13514$ x A. magna $\mathrm{V}$ 14707. In the male parent $A$. magna $\mathrm{V} 14707$ few bristles were observed on its stipules, but no bristles were seen on in the hybrid (Table 2).

\section{Morphological characterization of seedlings}

A) Arachis hybrid seedlings often show characteristics of their male parents in early growth stages, e.g., the shape of the leaflets and the hairiness of the epicotyl. If the epicotyl of the male parent seedling is villous, the epicotyl of the hybrid seedling will often also be villous (Table 3 and Figure 4A, B).

Table 3. Morphological characterization of the seedlings of Arachis parents and hybrids.

\begin{tabular}{|c|c|c|c|c|c|c|c|c|}
\hline \multirow[t]{2}{*}{ Parents } & \multicolumn{3}{|c|}{ Epicotyl } & \multicolumn{2}{|c|}{ Hypocotyl } & \multicolumn{3}{|c|}{ Cotyledons } \\
\hline & Length (mm) & Hairiness & Anthocyanin & Length (mm) & Anthocyanin & $\begin{array}{l}\text { Petioles } \\
\text { length }(\mathrm{mm})\end{array}$ & $\begin{array}{c}\text { Petioles } \\
\text { anthocyanin }\end{array}$ & $\begin{array}{l}\text { Cotyledon } \\
\text { anthocyanin }\end{array}$ \\
\hline A. gregoryi $\vee 14957$ & $26.1-126.7$ & villous & $-/+$ & $7.1-11.3$ & $-/+$ & $4.0-5.6$ & - & + \\
\hline A. ipaënsis K 30076 & $40.2-58.9$ & hairs & + & $8.9-29.1$ & $-1+$ & 4.5-7.4 & - & $-1+$ \\
\hline A. magna $\mathrm{K} 30097-\mathrm{of}$ & $13.0-98.8$ & hairs & $-1+$ & $8.9-20.2$ & $-1+$ & $2.7-6.8$ & + & $-1+$ \\
\hline A. magna $\mathrm{V} 14707$ & $21.4-60.2$ & hairs & $-1+$ & $10.5-30.0$ & $-/+$ & $2.7-6.0$ & - & - \\
\hline A. magna $\mathrm{V} 14724$ & $100.7-130.0$ & hairs & $-/+$ & $9.4-13.1$ & $-/+$ & $4.5-6.2$ & + & $-/+$ \\
\hline A. magna V 14727 & $50.7-121.5$ & hairs & + & $8.8-12.3$ & + & $4.8-6.2$ & - & $-/+$ \\
\hline A. valida $\vee 13514$ & $43.6-109.2$ & hairs & $-/+$ & $9.5-12.6$ & $-/+$ & $3.1-7.4$ & - & - \\
\hline A. valida V 15096 & $17.5-148.0$ & hairs & - & $9.0-10.4$ & + & $2.7-4.2$ & - & $-/+$ \\
\hline A. williamsii Wi 1118 & $93.9-120.2$ & hairs & + & $8.0-8.5$ & - & $4.1-5.0$ & - & - \\
\hline \multicolumn{9}{|c|}{ Cross combination A. valida V 13514 x } \\
\hline A. valida $\vee 15096$ & $19.9-25.5$ & hairs & + & $6.1-8.9$ & + & $3.4-5.0$ & + & - \\
\hline A. magna K 30097-of & $55.5-66.6$ & hairs & + & $9.8-12.8$ & + & $2.5-6.5$ & + & - \\
\hline A. magna $\vee 14727$ & $54.0-69.8$ & hairs & + & $6.5-8.6$ & + & $4.9-7.0$ & + & + \\
\hline A. williamsii Wi 1118 & $26.7-40.5$ & hairs & + & $5.9-7.1$ & + & $4.4-6.3$ & + & - \\
\hline A. magna V 14707 & 101.9 & hairs & + & 10.3 & - & $3.9-5.7$ & + & - \\
\hline A. gregoryi $\vee 14957$ & 28.1 & villous & + & 6.3 & + & $3.9-5.3$ & + & - \\
\hline A. ipaënsis K 30076 & 69.4 & hairs & + & 9.8 & + & $5.4-5.4$ & + & - \\
\hline A. magna $\mathrm{V} 14724$ & $8.3-38.5$ & hairs & + & $7.3-10.3$ & + & $4.4-6.7$ & $+/-$ & $+/-$ \\
\hline
\end{tabular}

Collector: $\mathrm{K}=\mathrm{A}$. Krapovickas, $\mathrm{V}=$ J.F.M. Valls, $\mathrm{Wi}=\mathrm{D} . \mathrm{E}$. Williams. of: orange flower, epicotyl length in millimeters $(\mathrm{mm})$, epicotyl hairiness, presence $(+)$ or absence $(-)$ of anthocyanin on epicotyl; hypocotyl length in millimeters $(\mathrm{mm})$, presence $(+)$ or absence $(-)$ of anthocyanin on hypocotyl; petiole length in millimeters $(\mathrm{mm})$; cotyledon length in millimeters $(\mathrm{mm})$; presence $(+)$ or absence $(-)$ of anthocyanin in petioles; and presence $(+)$ or absence $(-)$ of anthocyanin in cotyledons.

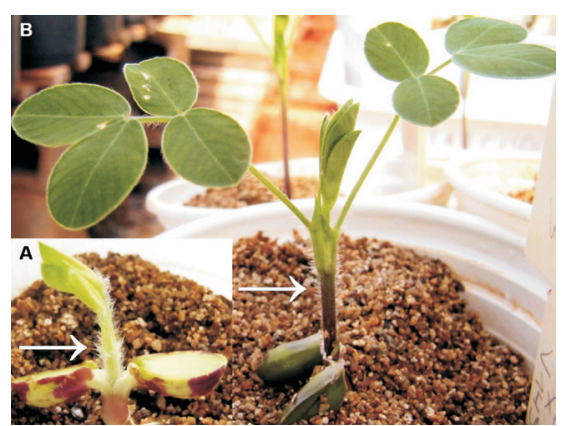

Figure 4. A. Seedling of male parent Arachis gregoryi $V 14957$ with villous epicotyl (arrow). B. Seedling of Arachis valida V 13514 x Arachis gregoryi $\vee 14957$ hybrid with villous epicotyl (arrow). 
B) In this study the length of the epicotyls of parent plants varied between $13.0 \mathrm{~mm}$ in $A$. magna $\mathrm{K}$ 30097-of to $148.0 \mathrm{~mm}$ in $A$. valida $\mathrm{V} 15096$. The length of the epicotyls of the hybrids varied between $8.3 \mathrm{~mm}$ in $A$. valida $\mathrm{V} 13514 \times$ A. magna $\mathrm{V} 14724$ and $101.9 \mathrm{~mm}$ in $A$. valida $\mathrm{V}$ 13514 x A. magna $\vee 14707$.

C) A characteristic that can assist in the identification of hybrid plants is the hairiness of the epicotyl. The female parent seedling A. valida $V 13514$ had hairs on the epicotyl; however, the epicotyl was not villous like that of the male parent $A$. gregoryi $\vee 14957$ (Table 3 ). Hairiness was only observed in the male parent $A$. gregoryi $\vee 14957$ and the hybrid $A$. valida $\vee 13514 \times A$. gregoryi $\mathrm{V} 14957$ (Figure 4A, B).

D) The presence or absence of anthocyanin in the epicotyl varied among the parent plants. All hybrids showed anthocyanin in the epicotyl (Figure 4B).

E) The length of the hypocotyls of parent plants varied between $7.1 \mathrm{~mm}$ in A. gregoryi V 14957 and $30.0 \mathrm{~mm}$ in $A$. magna $V 14707$. The shortest length of the hypocotyl of hybrids was 5.9 $\mathrm{mm}$ in $A$. valida $\mathrm{V} 13514 \times A$. williamsii Wi 1118 and the longest length was $12.8 \mathrm{~mm}$ in $A$. valida $V$ 13514 x A. magna K 30097-of (Table 3). The parents and the hybrids had no hairs on their hypocotyls. The presence or absence of anthocyanin in the hypocotyl varied among the parent plants. Only the hybrid $A$. valida $\mathrm{V} 13514 \times$ A. magna $\mathrm{V} 14707$ had no anthocyanin in the hypocotyl (Table 3).

F) The length of the petioles of the leaflets of the parent plants varied between $2.7 \mathrm{~mm}$ in A. magna K 30097-of, V 14707 and $A$. valida $\mathrm{V} 15096$ and $7.4 \mathrm{~mm}$ in $A$. ipaënsis $\mathrm{K} 30076$ and A. valida V 13514. Only the parents, A. magna K 30097-of and V 14724 had anthocyanin in their petioles. All the hybrids had anthocyanin in the petioles. The presence of anthocyanin in cotyledons varied among the parent plants. The cotyledons of the hybrids, A. valida $V 13514 \times A$. magna V 14727 had anthocyanin. In the hybrids, $A$. valida $V 13514$ x A. magna $V 14724$ presence or absence of anthocyanin was observed (Table 3 ). The surface of cotyledons of all parent plants and hybrid plants was furrowed (Figure 4A, B).

Variation of the same characteristics analyzed in the parent and hybrid seedlings of this study was observed in a study of germination of Arachis by Carpes (2010).

G) Contrary to AB Arachis hybrids, BB hybrids did not have precocious germination because they belong to the same genome and therefore experienced isolation barriers. This is a post-zygotic mechanism to decrease and/or avoid the development of hybrids obtained in the nature.

\section{Arachis valida crossability}

Arachis valida is a species with a $\mathrm{B}$ genome and has the potential to be used in a peanutbreeding program because of its resistance to diseases and pests (Pande and Rao, 2001; Ramos, 2007; Fávero et al., 2009). Data obtained in this study support $A$. valida as being of the $B$ genome because of the hybrids we were able to produce with $A$. gregoryi, $A$. ipaënsis, $A$. magna, and $A$. williamsii. By analysis of morphological characteristics and the low pollen viability estimates for the hybrids were confirmed. These data support the theory that the higher pollen viability indicates a higher probability for affinities between species and accessions (Fernández and Krapovickas, 1994; Robledo and Seijo, 2010; Custodio et al., 2013). The accession V 13514 of $A$. valida used in this study has high resistance to early and late leaf spot (Fávero et al., 2009), which are economically, important diseases in Brazil (Santos et al., 2013). Arachis valida V 15096, which was also used in this study, is resistant to corn caterpillar (Ramos, 2007). It will be possible to transfer these characteristics associated with known characteristics of other species of Arachis and to increase genetic variability in the peanut-breeding program. 


\section{Conflicts of interest}

The authors declare no conflict of interest.

\section{ACKNOWLEDGMENTS}

The authors would like to thank Programa Nacional de Apoio a Botânica (PNADB) of Coordenação de Aperfeiçoamento de Pessoal de Nível Superior (CAPES) for the scholarships granted to D.C. Wondracek-Lüdke, Conselho Nacional de Desenvolvimento Científico e Tecnológico (CNPq) CAPES/Embrapa for the scholarship granted to A.R. Custodio and CNPq for the Scientific Productivity grant presented to J.F.M. Valls.

\section{REFERENCES}

Anderson E (1949). Introgressive Hybridization. John Wiley \& Sons, New York/Chapman \& Hall, Limited, London.

Burow MD, Simpson CE, Faries MW, Starr JL, et al. (2009). Molecular biogeographic study of recently described B- and Agenome Arachis species, also providing new insights into the origins of cultivated peanut. Genome 52: 107-119.

Carpes GM (2010). Morfologia da germinação das espécies de Arachis (Fabaceae). Master's thesis, Universidade de Brasília, Brasília.

Cunha F, Nobile PM, Hoshino AA, Moretzsohn MC, et al. (2008). Genetic relationships among Arachis hypogaea L. (AABB) and diploid Arachis species with AA and BB genomes. Genet. Resour. Crop Evol. 55: 15-20.

Custodio AR (2009). Relações de cruzabilidade entre espécies e acessos de germoplasma do gênero Arachis associados ao genoma B do amendoim (Arachis hypogaea L.). Doctoral thesis, Universidade Federal de Santa Catarina, Florianópolis.

Custodio AR, Seijo G and Valls JFM (2013). Characterization of Brazilian accessions of wild Arachis species of section Arachis (Fabaceae) using heterochromatin detection and fluorescence in situ hybridization (FISH). Genet. Mol. Biol. 36: 364-370.

Einhardt PM, Correa ER and Raseira MCB (2006). Comparação entre métodos para testar a viabilidade de pólen de pessegueiro. Rev. Bras. Frutic. 28: 5-7.

FAOSTAT (2015). Food and Agriculture Organization of the United Nations Statistics Division. Available at [http://faostat3.fao. org/browse/Q/QD/E]. Accessed March 18, 2015.

Fávero AP (2004). Cruzabilidade entre espécies silvestres de Arachis visando à introgressão de genes de resistência a doenças no amendoim cultivado. Doctoral thesis, Universidade Estadual Paulista "Júlio de Mesquita Filho", Botucatu.

Fávero AP, Simpson CE, Valls JFM and Vello N (2006). Study of the evolution of cultivated peanut through crossability studies among Arachis ipaënsis, A. duranensis, and A. hypogaea. Crop Sci. 46: 1546-1522.

Fávero AP, Moraes SA, Garcia AAF, Valls JFM, et al. (2009). Characterization of rust, early and late leaf spot resistance on wild and cultivated peanut germplasm. Sci. Agric. 66: 110-117.

Grabiele M, Chalup L, Robledo G and Seijo G (2012). Genetic and geographic origin of domesticated peanut as evidenced by 5S rDNA and chloroplast DNA sequences. Plant Syst. Evol. 298: 1151-1165.

Gregory MP and Gregory WC (1979). Exotic germplasm of Arachis: interspecific hybrids. J. Hered. 70: 185-193.

Guerra M and Souza MJS (2002). Como Observar Cromossomos: Um Guia de Técnicas em Citogenética Vegetal, Animal e Humana. FUNPEC, Ribeirão Preto.

Holbrook CC, Timper P, Culbreath AK and Kvien CK (2008). Registration of 'Tifguard' peanut. J. Plant Regist. 2: 92-94.

Husted L (1933). Cytological studies on the peanut, Arachis. I: Chromosome number and morphology. Cytologia 5: 109-117.

Husted L (1936). Cytological studies on the peanut, Arachis. II: Chromosome number, morphology and behavior, and their application to the problem of the origin of the cultivated forms. Cytologia 7: 396-423.

IBPGR/ICRISAT(1992). Descriptors for groundnut. International Board for Plant Genetic Resources/International Crops Research for the Semi-Arid Tropics, Rome.

Kochert G, Stalker HT, Gimenes M, Galgaro L, et al. (1996). RFLP and cytogenetic evidence on the origin and evolution of allotetraploid domesticated peanut, Arachis hypogaea (Leguminosae). Am. J. Bot. 83: 1282-1291.

Krapovickas A and Gregory WC (1994). Taxonomía del género Arachis (Leguminosae). Bonplandia 8: 1-186.

Moretzsohn MC, Gouveia EG, Inglis PW, Leal-Bertioli SCM, et al. (2013). A study of the relationships of cultivated peanut (Arachis hypogaea) and its most closely related wild species using intron sequences and microsatellite markers. Ann. Bot. 111: 113-126. 
Nigam SN, Rao MJV and Gibbons RW (1990). Artificial hybridization in groundnut. International Crops Research Institute for the Semi-Arid Tropics, Patancheru.

Pande S and Rao N (2001). Resistance of wild Arachis species to late leaf spot and rust in greenhouse trials. Plant Dis. 85: $851-855$.

Peñaloza APS and Valls JFM (2005). Chromosome number and satellited chromosome morphology of eleven species of Arachis (Leguminosae). Bonplandia 14: 65-72.

Poole CF (1932). Pollen grain studies as an indication of fertility in hybrids. Genetics 17: 125-136.

Ramos VR (2007). Caracterização da resistência às cercosporioses, lagarta do cartucho e lagarta da soja em espécies silvestres do gênero Arachis, para uso no melhoramento genético do amendoim. Doctoral thesis, Universidade Estadual Paulista "Júlio de Mesquita Filho", Botucatu.

Robledo G and Seijo G (2010). Species relationships among the wild B genome of Arachis species (section Arachis) based on FISH mapping of DNAr loci and heterochromatin detection: a new proposal for genome arrangement. Theor. Appl. Genet. 121: 1033-1046.

Robledo G, Lavia GI and Seijo G (2009). Species relations among wild Arachis species with the A genome as revealed by FISH mapping of DNAr loci and heterochromatin detection. Theor. Appl. Genet. 118: 1295-1307.

Robledo G, Lavia GI and Seijo G (2010).Genome re-assignment of Arachis trinitensis (Sect. Arachis, Leguminosae) and its implications for the genetic origin of cultivated peanut. Genet. Mol. Biol. 33: 714-718.

Santos RC, Godoy IJ and Fávero AP (2013). O Agronegócio do Amendoim. In: Melhoramento do amendoim e cultivares comerciais (Santos RC, Freire RMM and Lima LM, eds). Embrapa, Brasília, 115-184.

Seijo JG, Lavia G, Fernández A, Krapovickas A, et al. (2004). Physical mapping of the 5S and 18S-25S rRNA genes by FISH as evidence that Arachis duranensis and A. ipaënsis are the wild diploid progenitors of $A$. hypogaea (Leguminosae). Am. J. Bot. 91: 1294-1303.

Silvestri MC, Ortiz AM and Lavia GI (2015). rDNA loci and heterochromatin positions support a distinct genome type for ' $\mathrm{x}=9$ species' of section Arachis (Arachis, Leguminosae). Plant Syst. Evol. 301: 555-562.

Stalker HT (1991). A new species in section Arachis of peanuts with a D genome. Am. J. Bot. 78: 630-637.

Stebbins GL (1958). The inviability, weakness, and sterility of interspecific hybrids. Adv. in Genet. 9: 147-215.

Tallury SP, Stalker HT and Pattee HE (1995). Early reproductive ontogeny in interspecific crosses of Arachis hypogaea and section Arachis species. Ann. Bot. 76: 397-404.

Valls JFM and Simpson CE (2005). New species of Arachis (Leguminosae) from Brazil, Paraguay and Bolivia. Bonplandia 14: 35-63.

Valls JFM, Costa LC and Custodio AR (2013). A novel trifoliolate species of Arachis (Fabaceae) and further comments on the taxonomic section Trierectoides. Bonplandia 22: 91-97. 